\title{
Vitamin D deficiency among children aged 10-18 years in Sri Lanka
}

\author{
Renuka Jayatissa ${ }^{1}$, Sarath Lekamwasam ${ }^{2}$, Jayawardana M Ranbanda ${ }^{1}$, Samantha Ranasingha ${ }^{1}$, \\ Amila G Perera ${ }^{1}$, Krishan H De Silva ${ }^{1}$
}

(Index words: vitamin D, adolescents, children 10-18 years, VDD)

\begin{abstract}
Background Vitamin D deficiency (VDD) and insufficiency (VDI) are public health problems in many countries, and limited data is available on the prevalence of VDD/VDI in Sri Lanka.

Objectives To determine the prevalence and associated factors of VDD in children aged 10-18 years.

Methods This was a cross-sectional study among school children aged 10-18 years at national level. A representative sample of 2525 children were recruited from July to November 2017. Serum 25(OH)D concentration and the patterns of vitamin $\mathrm{D}$ rich food consumption were assessed. VDD and VDI cut offs were set at serum $25(\mathrm{OH}) \mathrm{D}$ concentrations of $<12 \mathrm{ng} / \mathrm{mL}$ and $12-20 \mathrm{ng} /$ $\mathrm{mL}$, respectively as defined by global consensus in 2016 .

Results The mean serum 25(OH)D level was $19.3 \pm 7.4$ $\mathrm{ng} / \mathrm{mL}$. The prevalence of VDD and VDI were $13.2 \%(95 \%$ Cl: $11.9 \%-14.5 \%)$ and $45.6 \%$ (95\% Cl: $43.7 \%-47.5 \%)$, respectively. The prevalence of VDD was highest in the central province $(32.2 \%)$ and highest prevalence of VDI was in the Sabaragamuwa province (58.9\%). VDD and VDI were lowest in North Central province $(0.7 \%$ and $34.7 \%$, respectively). Significantly higher serum $25(\mathrm{OH}) \mathrm{D}$ levels were observed with male gender $(p=0.000)$, BMI for age $<-2 S D(p=0.000)$, daily milk consumption $(p=0.000)$ and residing in dry zone $(p=0.000)$.

Conclusions Though Sri Lanka is a tropical country, VDD is prevalent among school children aged 10-18 years. It is important to develop a VDD preventive strategy, especially for high risk groups.
\end{abstract}

Ceylon Medical Journal 2019; 64: 146-154

DOI: http://doi.org/10.4038/cmj.v64i4.8991

\section{Introduction}

During the past decade, interest in Vitamin D (VD) has increased due to the associations of VD with immune function, cardiovascular health, and even cancer occurrence as observed in multiple studies [1]. The clinical role of VD and its metabolites is expressive due to its interrelationship with calcium homeostasis and bone metabolism [2]. Vitamin D deficiency (VDD) presents as a pyramid with its severe most presentations being rickets in children and osteomalacia in adults at the top of the pyramid. These clinical presentations are rarely seen now a days but subclinical VDD, as detected by low serum 25-hydroxyvitamin $\mathrm{D}(25(\mathrm{OH}) \mathrm{D})$, is prevalent, VDD in children is an obstacle for them reaching their genetically programmed height and peak bone mass [3].

There is a disagreement about the best threshold of $25(\mathrm{OH}) \mathrm{D}$ levels to define VDD and VDI as the association between clinical presentations such as rickets or osteomalacia and levels of $25(\mathrm{OH}) \mathrm{D}$ has been inconsistent. This inconsistency is also seen between $25(\mathrm{OH}) \mathrm{D}$ level and biochemical markers such as elevated alkaline phosphatase. Thus, studies have adopted different methods to define cut-off values to determine VD sufficiency, insufficiency and deficiency [4].

There is a high prevalence of VDD worldwide when $25(\mathrm{OH}) \mathrm{D}$ threshold of $30 \mathrm{ng} / \mathrm{mL}$ is considered, whereas level below $10 \mathrm{ng} / \mathrm{mL}$ is common in South Asia and the Middle East [5]. A study revealed that more than $90 \%$ of patients aged 10-65 years were VDD when they presented with nonspecific muscle aches, bone aches and pain [6]. Identification and treatment of VDD is important for optimum musculoskeletal health [1]. VDD in children has been reported increasingly since the mid-1980s despite plentiful sunshine in some countries [7]. In Indian male and female adolescents the prevalence of severe VDD

${ }^{1}$ Medical Research Institute, Colombo 08, ${ }^{2}$ University of Ruhuna, Karapitiya, Sri Lanka.

Correspondence: RJ, e-mail: <renukajayatissa@ymail.com>. Received 16 August 2019 and revised version 12 November 2019 accepted 14 December 2019.

This is an open-access article distributed under the terms of the Creative Commons Attribution License, which permits unrestricted use, distribution, and reproduction in any medium, provided the original author and source are credited. 
$(<9.5 \mathrm{ng} / \mathrm{mL})$ was $27 \%$ and $47 \%$, respectively [8]. VDD $(<20 \mathrm{ng} / \mathrm{mL})$ prevails in the Middle East and North Africa, with rates varying from 30-90\% [7]. Female gender, winter season, lower vitamin D consumption and poor sunlight exposure due to cultural dress codes and pigmented skin were the risk factors of VDD identified in this study [7].

Sri Lanka is an island located near the equator between latitudes 5055' and 9051' $\mathrm{N}$ and longitudes 79041' and 81053 'E. It has a maximum land length and width of $432 \mathrm{~km}$ and $224 \mathrm{~km}$, respectively. Sri Lanka is a tropical country, with monthly average temperature varying between $26^{\circ} \mathrm{C}$ and $33^{\circ} \mathrm{C}$ in the lowlands and $7^{\circ} \mathrm{C}$ and $21.6^{\circ} \mathrm{C}$ in the central highlands. The country is divided according to the amount, seasonality and variability of rainfall into three zones (wet, intermediate and dry zones) [9]. Only a few studies on vitamin D have been conducted in Sri Lanka and these are either restricted to one region or adult populations $[10,11]$.

A study conducted in Southern Sri Lanka found severe $(25(\mathrm{OH}) \mathrm{D}<5.2 \mathrm{ng} / \mathrm{mL})$, moderate $(25(\mathrm{OH}) \mathrm{D} 5.2-10.0$ $\mathrm{ng} / \mathrm{mL})$, mild $(25(\mathrm{OH}) \mathrm{D} 10.1-14.0 \mathrm{ng} / \mathrm{mL})$ and overall VDD $(25(\mathrm{OH}) \mathrm{D} \leq 14 \mathrm{ng} / \mathrm{mL})$ among community-dwelling healthy women to be $21.4 \%, 19.1 \%, 15.7 \%$ and $56.2 \%$, respectively [10]. The age and sex adjusted prevalence of VDD $(25(\mathrm{OH}) \mathrm{D}<20 \mathrm{ng} / \mathrm{mL})$ and VD insufficiency (25(OH)D $20-30 \mathrm{ng} / \mathrm{mL})$ were $57.2 \%$ and $31 \%$, respectively in an adult Sri Lankan urban population [11].

Considering the high prevalence reported in these studies and limited data particularly in children, this study was conducted under the following objective: to determine the prevalence and associated factors of VDD in children aged 10-18 years in Sri Lanka at national and provincial levels.

\section{Methods}

\section{Data sources}

Data from the Sri Lankan national nutrition and micronutrient survey conducted among children aged 1018 years was used for analysis (12). The study design was a cross-sectional school-based survey and included 2700 adolescents aged 10-18 years. This study used a cluster random-sampling technique and clusters were defined as all government schools excluding primary schools. The government school system retains about $80 \%$ of children between 10-17 years in Sri Lanka [13]. From each province 15 schools, selected randomly, were studied (a total of 135 schools). In each selected class, 20 adolescents (10 male and 10 female) were randomly selected using attendance registers. The survey was conducted from July to November 2017. Children answered a food frequency questionnaire, which was validated through similar previous surveys conducted by the Medical Research Institute (MRI) to determine the daily consumption of vitamin D rich food items. Among the food consumed by the children, it was found that only milk and biscuit contain a considerable quantity of vitamin $\mathrm{D}$. Therefore, average vitamin $\mathrm{D}$ content of milk and biscuits was obtained by conducting a market survey and scanning food labels. The Indian food composition tables were used for all other food items [14]. Weight and height were measured by trained MRI staff using UNICEF UNISCALES and stadiometer, while adhering to the WHO standardized techniques in recording the measurements to the nearest $0.1 \mathrm{~kg}$ and $0.1 \mathrm{~cm}$, respectively [15]. The parents of children provided written informed consent before their enrolment in the study. Ethical clearance was obtained from the MRI ethics committee.

\section{Laboratory methods}

Blood samples were collected from 2525 children (93.5\% of the sample) by venepuncture to red-top tubes by qualified nurses at designated centres. Blood was allowed to clot at room temperature and then centrifuged to separate serum within 2 hours of collection by the medical laboratory technologists. Serum samples were stored at $-20^{\circ} \mathrm{C}$ for maximum of 5 days until transported with ice packs to the central laboratory every week and then stored at $-80^{\circ} \mathrm{C}$ until the analysis. Serum $25(\mathrm{OH}) \mathrm{D}$ was quantified by chemiluminescence immunoassays (DiaSorin, Italy) with sensitivity of $\leq 4.0 \mathrm{ng} 25(\mathrm{OH}) \mathrm{D} / \mathrm{mL}$. The reference standard was run on the analyser to check for correct calibration and fraction before the samples were analysed. Internal commercially prepared quality control samples (LIASON level 1 and 2) were included in every batch to determine between-batch precision of the assays. Samples of $25(\mathrm{OH}) \mathrm{D}$ concentrations below $12 \mathrm{ng} / \mathrm{mL}$ and above $40 \mathrm{ng} / \mathrm{mL}$ were analysed in duplicates. The inter assay coefficient variance $(\mathrm{CV})$ was $4.9 \%$. Intra-assay level 1 and intra-assay level $2 \mathrm{CV}$ were $7.5 \%$ (mean 16.8 1.3 ) and $5.9 \%$ (mean 53.6 \pm 3.2 ), respectively.

\section{Data analysis}

IBM Statistical Package for Social Sciences ${ }^{\circledR}$ (SPSS) version 23.0 was used for statistical analyses. Serum $25(\mathrm{OH}) \mathrm{D}$ levels was expressed as mean $\pm \mathrm{SD}$. Chi-square test, Mann Whitney U test and F test were used to determine the factors associated with serum $25(\mathrm{OH}) \mathrm{D}$ level. The $\mathrm{p}<0.05$ was considered as statistically significant. In the original dataset, age was calculated with birthdays extracted from the class attendance register that was available for all the children. Weight and height were analysed using the WHO Anthro-Plus 2009 software [16]. Child nutritional status was classified according to BMIfor-age-sex as thin (<-2SD), adequate (between -2SD to $+1 \mathrm{SD}$ ), overweight (between $+1 \mathrm{SD}$ to $+2 \mathrm{SD}$ ) or obese $(>+2 \mathrm{SD})$ and linear growth was classified according to height-for-age as stunted (<-2SD), or adequate $(\geq-2 \mathrm{SD})$ as defined by the WHO [15]. We categorized vitamin D status as sufficient, insufficient and deficient when $25(\mathrm{OH})$ D concentrations were $>20-100 \mathrm{ng} / \mathrm{mL}, 12-20 \mathrm{ng} /$ $\mathrm{mL}$ and $<12 \mathrm{ng} / \mathrm{mL}$, respectively according to the global 
guidelines [17]. Parathyroid hormonal level was performed in a 300-sub sample to reconfirm the cut-off level (details are not provided in this paper).

\section{Results}

A total of 2525 children ( $53.3 \%$ female) were included in the study. Mean age of the sample was $14.0 \pm 2.0$ years. In the study sample, mean BMI was $17.8 \pm 3.5 \mathrm{~kg} / \mathrm{m}^{2}$ and it ranged from 10.7 to $41.0 \mathrm{~kg} / \mathrm{m}^{2}$. Percentages of stunting, thinness, overweight and obesity in the study sample were 13.4, 27.0, 8.5 and 2.2, respectively (Table 1). Among the study subjects, the prevalence of VDD, VDI, VDS were $13.2 \%$ (95\% CI: $11.9 \%-14.5 \%), 45.6 \%$ (95\% CI: $43.7 \%-47.5 \%$ ) and $41.2 \%$ (95\% CI: $39.3 \%-43.1 \%)$, respectively (Table 2). There was a higher percentage of VDD in females than in males (18.9 Vs 6.7; $\mathrm{p}=<0.001)$. Overweight children had a higher prevalence of VDD compared to thin children (16.4 Vs 11.0; $\mathrm{p}=<0.001)$. There was a wide variation in VDD prevalence between provinces. The highest prevalence was found in the Central province and the lowest in the North Central province (32.2\% [95\% CI:26.8\%-37.6\%] Vs 0.7\% [95\% CI: - 0.3\%$1.7 \%$ ]; $\mathrm{P}=<0.001)$. There was no significant difference in VDD within age groups and also between stunted vs nonstunted. Mean serum 25(OH)D level in the study sample was $19.3 \pm 7.4 \mathrm{ng} / \mathrm{mL}$ and ranged from 4.0 to $70.0 \mathrm{ng} / \mathrm{mL}$. It was observed that, among boys of all age groups, mean serum 25(OH)D concentrations (20.6-23.8 ng/mL) were above the cut-off level of VDS. Among girls of all age groups, mean $25(\mathrm{OH}) \mathrm{D}$ levels were below the cut-off for VDI (16.7-18.1 ng/mL). Mean serum 25(OH)D level in thin children was significantly higher compared to obese children $(20.9 \pm 8.0$ Vs $16.4 \pm 4.9 \mathrm{ng} / \mathrm{mL} ; \mathrm{p}<0.001)$. Mean $25(\mathrm{OH}) \mathrm{D}$ level significantly varied between provinces (14.6-24.1 ng/mL; $\mathrm{p}<0.001)$. The highest mean 25(OH)D levels was observed in the North Central province $(24.1 \pm 8.3$ $\mathrm{ng} / \mathrm{mL}$ ) while the lowest in the Sabaragamuwa province $(14.6 \pm 4.9 \mathrm{ng} / \mathrm{mL})$. Commonly consumed vitamin D rich daily food items were milk and biscuits. Though fish contains the highest amount of vitamin D, $70.3 \%$ of children consumed fish, only 2-3 times per week. Second highest food source of vitamin D was milk. One serving of milk $(20 \mathrm{~g})$ contained $3.6 \pm 2.5 \mu \mathrm{g}$ of vitamin $\mathrm{D}$ due to fortification. It was observed that $21.2 \%, 26.4 \%$ and $29.1 \%$ of children had never consumed margarine, butter or cheese, respectively (Table 4). Table 5 shows, the multiple regression analysis, the variables account for $22 \%$ of the variance in $25(\mathrm{OH}) \mathrm{D}$ levels. Female gender, living in Sabaragamuwa or Central province, being obese or overweight showed significant negative correlations with serum 25(OH)D level. Living in North Central or North Western provinces, being thin and consuming milk daily showed significant positive correlations with serum $25(\mathrm{OH}) \mathrm{D}$ level.

Table 1. Baseline information of study sample

\begin{tabular}{|c|c|}
\hline $\begin{array}{l}\text { Child and household } \\
\text { characteristics }\end{array}$ & $\begin{array}{c}\text { Mean } \pm S D / \\
\text { No }(\%) / \%(C I)\end{array}$ \\
\hline \multicolumn{2}{|l|}{ Child's sex } \\
\hline Boys (n) & $1178(46.7)$ \\
\hline Girls (n) & $1347(53.3)$ \\
\hline \multicolumn{2}{|l|}{ Age (years) } \\
\hline Mean \pm SD & $14.0 \pm 2.0$ \\
\hline \multicolumn{2}{|l|}{ Nutritional status of children } \\
\hline Mean HAZ score & $-1.0 \pm 0.9$ \\
\hline Mean BMI Z score & $-1.1 \pm 1.4$ \\
\hline Mean $\mathrm{BMI} \pm \mathrm{SD}\left(\mathrm{kg} / \mathrm{h}^{2}\right)$ & $17.8 \pm 3.5$ \\
\hline BMI range $\left(\mathrm{kg} / \mathrm{h}^{2}\right)$ & $10.7-41.0$ \\
\hline Stunting (height-for-age $<-2 \mathrm{SD}$ ) & $13.4(12.1-14.7)$ \\
\hline Thin $($ BMI-for-age-sex $<-2 \mathrm{SD})$ & $27.0(25.3-28.7)$ \\
\hline Overweight (BMI-for-age-sex $>+1 \mathrm{SD}$ ) & $8.5(7.4-9.6)$ \\
\hline Obesity (BMI-for-age-sex > + 2SD) & $2.2(1.6-2.8)$ \\
\hline Total & $2525(100.0)$ \\
\hline
\end{tabular}

HAZ - height for age Z score; BMI Z score - Body Mass Index Z score 
Table 2. Prevalence/percentage of VDD, VDI, VDS in children aged 10-18 years by child characteristics and place of residence

\begin{tabular}{|c|c|c|c|c|}
\hline \multicolumn{5}{|c|}{$25(\mathrm{OH})$ D level (\% and confidence interval) } \\
\hline $\begin{array}{l}\text { Child characteristics and } \\
\text { place of residence }\end{array}$ & No of subjects & $\begin{array}{l}<12 \\
V D D\end{array}$ & $\begin{array}{l}12-20 \\
\text { VDI }\end{array}$ & $\begin{array}{l}20-100 \\
\text { VDS }\end{array}$ \\
\hline \multicolumn{5}{|l|}{ Sex* } \\
\hline Girls & 1347 & 18.9 & 50.3 & 30.8 \\
\hline Boys & 1178 & 6.7 & 40.2 & 53.1 \\
\hline \multicolumn{5}{|l|}{ Age in years } \\
\hline 10 & 91 & 8.8 & 48.4 & 42.9 \\
\hline 11 & 292 & 12.3 & 43.2 & 44.5 \\
\hline 12 & 266 & 9.8 & 51.9 & 38.3 \\
\hline 13 & 303 & 11.6 & 46.2 & 42.2 \\
\hline 14 & 422 & 15.9 & 46.2 & 37.9 \\
\hline 15 & 534 & 13.7 & 45.3 & 41.0 \\
\hline 16 & 405 & 12.3 & 43.2 & 44.4 \\
\hline $17-18$ & 212 & 17.9 & 42.9 & 39.2 \\
\hline \multicolumn{5}{|l|}{ Height group } \\
\hline Stunted & 339 & 13.3 & 44.5 & 42.2 \\
\hline Not stunted & 2186 & 13.2 & 45.7 & 41.1 \\
\hline \multicolumn{5}{|l|}{ BMI group* } \\
\hline Thin & 681 & 11.0 & 37.2 & 51.8 \\
\hline Adequate & 1600 & 13.7 & 48.4 & 37.9 \\
\hline Overweight & 189 & 16.4 & 47.1 & 36.5 \\
\hline Obese & 55 & 14.5 & 61.8 & 23.6 \\
\hline \multicolumn{5}{|l|}{ Province $^{*}$} \\
\hline North Central & 271 & $0.7(-0.3-1.7)$ & $34.7(29.0-40.4)$ & $64.6(58.9-70.3)$ \\
\hline North Western & 270 & $1.9(0.3-3.5)$ & $37.0(31.2-42.8)$ & $67.1(61.5-72.7)$ \\
\hline Northern & 287 & $8.7(5.4-12.0)$ & $44.9(39.2-50.7)$ & $46.3(40.5-52.1)$ \\
\hline Western & 280 & $8.9(5.6-12.2)$ & $45.7(39.9-51.5)$ & $45.4(39.6-51.2)$ \\
\hline Eastern & 288 & $11.1(7.5-14.7)$ & $51.4(45.6-57.2)$ & $37.5(31.9-43.1)$ \\
\hline Southern & 277 & $13.0(9.1-16.9)$ & $45.8(40.0-51.6)$ & $41.2(35.5-46.9)$ \\
\hline Uva & 296 & $13.5(9.6-17.5)$ & $46.3(40.5-52.1)$ & $40.2(34.5-45.9)$ \\
\hline Sabaragamuwa & 280 & $28.2(23.0-33.4)$ & $58.9(53.2-64.6)$ & $12.9(9.0-16.8)$ \\
\hline Central & 276 & $32.2(26.8-37.6)$ & $44.6(38.9-50.4)$ & $23.2(18.3-28.1)$ \\
\hline Total $(95 \% \mathrm{CI})$ & 2525 & $13.2(11.9-14.5)$ & $45.6(43.7-47.5)$ & $41.2(39.3-43.1)$ \\
\hline
\end{tabular}

$* \mathrm{P}=<0.001$. 
Table 3. Mean serum 25OHD levels in children aged 10-18 years by age, sex and province

\begin{tabular}{|c|c|c|c|}
\hline \multicolumn{2}{|c|}{ Age and sex } & \multicolumn{2}{|c|}{ Mean serum $25 O H D$ levels } \\
\hline Sex* & Age in years & No of subjects & $N G / M L$ \\
\hline Female & 10 & 46 & $18.1(6.2)$ \\
\hline 11 & 148 & $17.4(6.2)$ & \\
\hline 12 & 132 & $16.8(5.9)$ & \\
\hline 13 & 168 & $16.9(6.0)$ & \\
\hline 14 & 234 & $16.7(6.8)$ & \\
\hline 15 & 264 & $18.0(6.5)$ & \\
\hline 16 & 220 & $18.0(7.1)$ & \\
\hline $17-18$ & 135 & $17.5(6.6)$ & \\
\hline Total & & 1347 & $17.4(6.5)$ \\
\hline Male & 10 & 45 & $23.8(9.5)$ \\
\hline 11 & 144 & $21.5(6.3)$ & \\
\hline 12 & 134 & $21.2(6.8)$ & \\
\hline 13 & 135 & $22.2(8.4)$ & \\
\hline 14 & 188 & $21.7(8.2)$ & \\
\hline 15 & 270 & $20.6(7.9)$ & \\
\hline 16 & 185 & $21.7(7.9)$ & \\
\hline $17-18$ & 77 & $21.0(7.5)$ & \\
\hline Total & & 1178 & $21.5(7.8)$ \\
\hline Both sex & 10 & 91 & $20.9(8.5)$ \\
\hline 11 & 292 & $19.4(6.6)$ & \\
\hline 12 & 266 & $19.0(6.8)$ & \\
\hline 13 & 303 & $19.2(7.6)$ & \\
\hline 14 & 422 & $18.9(7.8)$ & \\
\hline 15 & 534 & $19.3(7.4)$ & \\
\hline 16 & 405 & $19.7(7.7)$ & \\
\hline $17-18$ & 212 & $18.8(7.2)$ & \\
\hline \multicolumn{4}{|l|}{ Province* } \\
\hline North Central & & 271 & $24.1(8.3)$ \\
\hline North Western & & 270 & $22.4(6.7)$ \\
\hline Northern & & 287 & $19.8(6.5)$ \\
\hline Western & & 280 & $19.5(6.2)$ \\
\hline Uva & & 296 & $19.5(8.2)$ \\
\hline Eastern & & 288 & $19.3(7.0)$ \\
\hline Southern & & 277 & $19.0(6.9)$ \\
\hline Central & & 276 & $15.5(6.8)$ \\
\hline Sabaragamuwa & & 280 & $14.6(4.9)$ \\
\hline \multicolumn{4}{|l|}{ BMI categories* } \\
\hline Thin & & 681 & $20.9(8.0)$ \\
\hline Adequate & & 1600 & $18.9(7.2)$ \\
\hline Overweight & & 189 & $18.0(6.3)$ \\
\hline Obese & & 55 & $16.4(4.9)$ \\
\hline Total & & 2525 & $19.3(7.4)$ \\
\hline
\end{tabular}


Table 4. Daily consumption of vitamin D rich food items among children aged 10-18 years and vitamin $D$ content of typical serving size

\begin{tabular}{|c|c|c|c|c|c|c|c|}
\hline \multirow{5}{*}{$\begin{array}{l}\text { Vitamin D rich } \\
\text { food items }\end{array}$} & \multirow{5}{*}{$\begin{array}{c}\text { Serving size } \\
\text { of food }\end{array}$} & \multirow{5}{*}{$\begin{array}{c}\text { Vitamin } D(\mu G) \\
\text { in a serving } \\
\text { mean } \pm S D\end{array}$} & \multicolumn{5}{|c|}{ Consumption frequency (\%) } \\
\hline & & & More & Daily & & Seldom & Never \\
\hline & & & than & & times & & \\
\hline & & & once & & per & & \\
\hline & & & /daily & & week & & \\
\hline $\begin{array}{l}\text { Fish (small and } \\
\text { big, shell, dry fish) }\end{array}$ & $30 \mathrm{~g}$ & $5.4 \pm 8.0^{2}$ & 0.2 & 3.9 & 70.3 & 23.5 & 2.1 \\
\hline Milk powder / liquid & $20 \mathrm{~g} / 100 \mathrm{ml}$ & $3.6 \pm 2.5^{1}$ & 17.8 & 35.4 & 13.0 & 30.7 & 3.1 \\
\hline Margarine & $10 \mathrm{~g}$ & $1.6 \pm 0.1^{1}$ & 0.0 & 0.2 & 7.0 & 71.6 & 21.2 \\
\hline Biscuits & $30 \mathrm{~g}$ & $0.6 \pm 0.5^{1}$ & 1.6 & 17.9 & 49.5 & 30.5 & 0.6 \\
\hline Yogurt & $80 \mathrm{~g}$ & $0.7^{2}$ & 0.0 & 0.9 & 21.8 & 73.0 & 4.3 \\
\hline Cheese & 1 slice & $0.2^{2}$ & 0.0 & 0.2 & 3.6 & 67.0 & 29.1 \\
\hline Egg & 1 egg $(60 g)$ & $1.0^{2}$ & 0.0 & 1.1 & 44.4 & 50.5 & 3.9 \\
\hline Butter & $10 G$ & $0.02^{2}$ & 0.0 & 0.2 & 5.3 & 68.0 & 26.4 \\
\hline
\end{tabular}

${ }^{1}$ Values obtained through the market survey and averaged;

${ }^{2}$ Values were obtained from Indian food composition table

Table 5. Child characteristics in relation to serum 25OHD levels, VDD, VDI and VS children years aged 10-18 of as identified by multiple regression analysis

\begin{tabular}{|c|c|c|c|c|}
\hline Child and household characteristics & $B$ & $S E$ & $P$ & $\begin{array}{c}\text { Confidence } \\
\text { interval }\end{array}$ \\
\hline \multicolumn{5}{|l|}{ Serum $25 \mathrm{OHD}$ levels $\mathrm{ng} / \mathrm{ml}^{\circ}$} \\
\hline Living in north central province vs other provinces & 4.6 & 0.4 & .000 & $3.7-5.4$ \\
\hline Living in north western province vs other & 2.9 & 0.4 & .000 & $2.1-3.8$ \\
\hline Children consumed milk daily vs other & 1.4 & 0.3 & .000 & $0.8-2.0$ \\
\hline Thin children vs other & 1.2 & 0.3 & .000 & $0.6-1.8$ \\
\hline Children consumed milk 2-3 times per day vs other & 1.1 & 0.4 & .003 & $0.4-1.8$ \\
\hline Living in Sabaragamuma province vs other provinces & -4.8 & 0.4 & .000 & $-5.6--4.0$ \\
\hline Living in central province vs other provinces & -4.0 & 0.4 & .000 & $-4.8--3.1$ \\
\hline Female vs male & -3.7 & 0.3 & .000 & $-4.2--3.1$ \\
\hline Obesity children vs other & -3.2 & 0.9 & .000 & $-4.9--1.4$ \\
\hline Overweight children vs other & -1.2 & 0.5 & .017 & $-2.2--0.2$ \\
\hline
\end{tabular}

$\cdot F(10,2514)=73.7, P<0.000, R^{2}=0.22$ 


\section{Discussion}

This is the first national study which assessed VDD in children aged 10-18 years in Sri Lanka. Although Sri Lanka is a tropical country with sunlight throughout the year with ample opportunity to obtain sun exposure, we found $13.2 \%$ and $45.6 \%$ of children aged $10-18$ years to have VDD and VDI, respectively according to the cut-off provided in the recent global consensus [17].

We measured serum $25(\mathrm{OH}) \mathrm{D}$ concentration to assess the vitamin D status, which is the gold standard. It reflects the amount of vitamin $\mathrm{D}$ taken from the diet and that produced in the skin in response to sunlight (UVB) exposure [5]. The use of diverse cut-offs for VDD and laboratory techniques to detect $25(\mathrm{OH}) \mathrm{D}$ in previous studies made it difficult to make a comparison between studies [18-24]. The criterion standard method of testing $25(\mathrm{OH}) \mathrm{D}$ is liquid chromatography mass spectrometry (LC/ MS) and in our study immunoassay was used. There is minimum variability between results of immunoassays and LC/MS at low 25(OH)D concentrations [25-26]. Hence using immunoassays in our study may not have affected the validity of test results due to high prevalence of low $25(\mathrm{OH}) \mathrm{D}$ concentrations in our sample.

The mean serum 25(OH)D concentrations of our study subjects was $19.3 \pm 7.4 \mathrm{ng} / \mathrm{mL}$, which is lower than the cut off defined by global consensus ( $\geq 20 \mathrm{ng} / \mathrm{mL}$ ) [17]. These results are consistent with studies involving children in other countries. Vitamin D insufficiency $(<20 \mathrm{ng} / \mathrm{mL})$ varied from 5-57\% in children of other tropical countries and also among other age groups used for studies already conducted in Sri Lanka [10-11, 26-32].

Our results suggest that the vitamin D status of children in our study group was positively associated with male gender, low BMI for age-sex, dry zone lowlands and consuming milk daily. Vitamin D status was negatively associated with living in wet zone highlands and obesity. It was not associated with stunting and age.

Similar to results reported in other studies, male had a lower prevalence of VDD compared to females [26-32] and this pattern was noted in all age groups. This could partly be due to males having more sun exposure because of the tendency of males to engage in outdoor sports more than females.

Considering BMI for age-sex, 13.4\%, 27.0\%, 8.5\% and $2.2 \%$ of children in our study sample were stunted, thin, overweight and obese, respectively. We found no association between stunting and VDD. The highest VDD was found in obese children and the lowest in thin children. Other studies also found a similar association between VDD and BMI [31-32].

There was a marked difference in mean $25(\mathrm{OH}) \mathrm{D}$ concentrations between provinces highlighting the need for further studies. We found a higher prevalence of VDD in Sabaragamuwa and Central provinces and these provinces are situated in the wet zone highlands of the country. There is frequent rainfall and a colder climate (average $16^{\circ} \mathrm{C}$ ) when compared with other parts of the country. Conversely lower prevalence of VDD was reported from the North Western and North Central provinces, which are situated in the dry zone lowlands.

The primary determinant of vitamin D status in any population is the exposure to ultraviolet-B (UV-B) rays. VDD is associated with limited outdoor activity during the midday due to hot climate or scorching sun, dark skin pigmentation and covering up of the body due to the cold climate or cultural reasons etc. [5]. Our study group was comprised of school children and schools function from 7.30 A.M. to 1.30 P.M. providing an opportunity for the children to get exposed to UV-B at peak hours: from 10 A.M. to 3 P.M. [5]. Typical Sri Lankan school uniforms allow for $20-50 \%$ body skin exposure and with $35-40$ minutes of peak UV-B exposure, this is sufficient to obtain the daily vitamin D requirement [34]. The results of our study indicate that the average sun exposure during their daily activities was insufficient for almost half of this study group to synthesize the daily requirement of vitamin D. Therefore, we need in-depth studies on sunlight exposure and vitamin D status in Sri Lankan children to decide on the conditions of VD production and safety issue. More than 35-40 minutes of high UV index sun exposure may not be safe due to the increased risk of eye damage and damage to the immune system $[35,36]$.

Daily consumption of food rich in vitamin D was low in the study sample but of all the vitamin D rich foods, milk was a part of the daily diet in $50 \%$ of this population. Our study showed, most of the milk powder in the market was fortified with vitamin $\mathrm{D}$, however this fortification may be inadequate for this population and adequately fortified milk powder could be used as an alternative source of vitamin D.

This study has a few limitations. First, data were collected from school children and children out of school were not included. However, $80 \%$ of children between 10-18 years are school going in Sri Lanka. Second, blood samples were collected during the period of June to November, which are the monsoon months meaning there is more rainfall to the wetland areas and colder climate in the highlands but also signifies drought season for the dry zone areas. As a result, the data presented most likely represents the worst-case scenario for wet zone highland areas and best-case scenario for dry zone lowlands. Third, all risk factors associated with VDD were not analysed (eg. season, latitude, colour of the skin, cultural dress habits, estimated sunlight exposure, calcium levels etc.) in this study.

\section{Conclusion}

Though Sri Lanka is a tropical country, vitamin D deficiency is an emerging problem in children aged 10-18 years. It highlights the need to adopt strategies to prevent 
VDD in this population. We need to raise awareness and promote active outdoor activity to get safe sun exposure to obtain the optimum daily vitamin $\mathrm{D}$ requirements. It is also important to promote the consumption of vitamin D fortified food in this population.

\section{Acknowledgements}

We thank staff of Department of Nutrition, Medical Research Institute, Ministry of Health, Sri Lanka for conducting the national survey and all the participants of the study. This research received no specific grant from any funding agency in the public, commercial, or not-forprofit sectors.

\section{Author contributions}

Renuka Jayatissa and Sarath Lekamwasam conceptualised, designed and wrote the paper. Ranbanda Jayawardana, Samantha Ranasinghe, Amila Perera, and KH De Silva conducted the national survey, analysed the data set and assist to write the paper. All authors read the manuscript, made a substantial contribution to the revision and approved the final manuscript.

\section{Conflicts of interest}

The opinions expressed are those of the authors do not necessarily reflect the views of the institutions that they are affiliated with. The authors declare that there are no conflicts of interest.

\section{References}

1. Holick MF. Sunlight and vitamin D for bone health and prevention of autoimmune diseases, cancers, and cardiovascular disease. Am J Clin Nutr 2004; 80(suppl): 1678S$88 \mathrm{~S}$.

2. Sunil J Wimalawansa. Vitamin D: what clinicians need to know. Sri Lanka Journal of Diabetes, Endocrinology and Metabolism 2012; 2(2): 73-88.

3. Misra M. Vitamin D insufficiency and deficiency in children and adolescents. UpToDate 2019 May. https://www. uptodate.com/contents/vitamin-d-insufficiency-anddeficiency-in-children-and-adolescents (Accessed on September 28, 2018).

4. Holick MF, Binkley NC, Bischoff-Ferrari HA, et al. Evaluation, treatment and prevention of vitamin D deficiency: an Endocrine Society clinical practice guideline. J Clin Endocrinol Metab 2011; 96: 1911.

5. Holick MF. The vitamin D deficiency pandemic: Approaches for diagnosis, treatment and prevention. Rev Endocr Metab Disord 2017; 18: 153-65.

6. Plotnikoff GA, Quigley JM. Prevalence of severe hypovitaminosis D in patients with persistent, nonspecific musculoskeletal pain. Mayo Clin Proc 2003; 78: 1463-70.
7. Lewis L. Tackling vitamin D deficiency in children and atrisk families. Primary Health Care 2014; 24(4): 20-24.

8. Soliman AT, De Sanctis V, Elalaily R, Bedair S, Kassem I. Vitamin D deficiency in adolescents. Indian Journal of Endocrinology and Metabolism 2014; 18(1): S9-S15.

9. Peiris GH, Arasaratnam S. Sri Lanka 2018. https:// www.britannica.com/place/Sri-Lanka. Accessed on September, 29, 2018.

10. Rodrigo M, Hettiarachchi M, Liyanage C, Lekamwasam S. Low serum vitamin D among community-dwelling healthy women in Sri Lanka. Health 2013; 5(12): 1997- 2003. http:/ /dx.doi.org/10.4236/health.2013.51227

11. Gunawardane K, Somasundaram N, Thalagala N, Chulasiri $\mathrm{P}$, Fernando S. Prevalence of vitamin D deficiency and its association with diabetes in a South-Asian population. Endocrine Abstracts 2015; 38: 273 DOI: 10.1530/endoabs. 38.P273

12. Medical Research Institute. National nutrition and micronutrient survey among school adolescents aged 10-18 years in Sri Lanka - 2017. Ministry of health. 2019.

13. UNESCO. Sri Lanka Education system. http://www.uis. unesco.org/ country/LK. Accessed on September, 29, 2018.

14. Longvah T, Ananthan R, Bhaskarachary K and Venkaiah K. Indian Food Composition Tables. National Institute of Nutrition: Hydrabad 2017.

15. World Health Organisation. Physical Status: The Use and Interpretation of Anthropometry; WHO: Geneva, Switzerland 1995.

16. World Health Organisation. WHO Anthro Plus for personal computers Manual: Software for assessing growth of the world's children and adolescents. Geneva: WHO, 2009 (http://www.who.int/growthref/tools/en/).

17. Munns CF, Shaw N, Kiely M, Specker BL, Thacher TD, Ozono $\mathrm{K}$, et al. Global consensus recommendations on prevention and management of nutritional rickets. J Clin Endocrinolol Metab. 2016; 101(2): 394-415.

18. Kapil U, Pandey RH, Goswami R, Sharma B, Sharma N, Ramakrishnan L, Singh G, Sareen N, Sati HC, Gupta A, Sofi NY. Prevalence of vitamin D deficiency and associated factors among children residing at high altitude in Shimla district, Himachal Pradesh, India. Indian Journal of Endocrinology and Metabolism 2017; 21(1): 178-83.

19. Gordon CM, DePeter KC, Feldman HA, Grace E, Emans J. Prevalence of vitamin D deficiency among healthy adolescents. Arch Paediatr Adolesc Med 2004; 158: 531-37.

20. Alyahya KO, Vitamin D levels in schoolchildren: a crosssectional study in Kuwait. BMC Paediatrics 2017; 17: 213.

21. Roh YE, Kim AR, Choi WB, Kim YM, Cho M, Kim H, Park KH, Kim KH, Chun P, Kim SY, Kwak MJ. Vitamin D deficiency in children aged 6-12 years: single center's experience in Busan. Annals of Paediatrics Endocrinology and Metabolism 2016; 21: 149-54. 
22. Mansour MMHK, Alhadidi KM. Vitamin D deficiency in children living in Jeddah, Saudi Arabia. Indian Journal of Endocrinology and Metabolism 2012; 16(2): 263-69.

23. Dyson A, Pizzutto SLJ, MacLennan C, Stone M and Chang $\mathrm{AB}$. The prevalence of vitamin D deficiency in children in the Northern Territority. Journal of Paediatrics and Child Health 2014; 50: 47-50.

24. Wang S, Shen G, Jiang S, Xu H, Li M, Wang Z, Zhang Su and Yu Y. Nutrient status of vitamin D among Chinese children. Nutrients 2017; 9: 319.

25. Black LJ, Anderson D, Clarke MW, Ponsonby AL, Lucas RM. Ausimmune Investigator Group. Analytical bias in the measurement of serum 25-hydroxyvitamin D concentrations impairs assessment of vitamin D status in clinical and research settings. PLoS One 2015; 10(8): $135-478$.

26. Cashman KD, Kiely M, Kinsella M, Durazo-Arvizn RA, Tian L, Zhang Y, Lucey A, Flynn A, Gibney MJ, Vesper HW, Phinney KW, Coater PM, Picciano MF, Sempos CT. Evaluation of vitamin D standardization programme protocols for standardizing serum 25-hydroxyvitamin D data: a case study of the program's potential for national nutrition and health surveys. American Journal of Clinical Nutrition 2013; 97: 1235-42.

27. Susanna Y, Catherine H, Gordon M. Vitamin D deficiency in children and adolescents: Epidemiology, impact and treatment. Reviews in Endocrine and Metabolic Disorders 2008; 9(2): 161-70.

28. Cashman KD. Vitamin D in childhood and adolescence Postgrad Med J. 2007; 83(978): 230-235. doi:10.1136/ pgmj.2006.052787 (Accessed on September 28, 2018).

29. Misra M, Motil KJ, Drezner MK, Hoppin AG. Up to date on Vitamin D insufficiency and deficiency in children and adolescents. Available at: https://uptodate.yhdp.vn/
contents/UTD.htm?27/38/28266/abstract/5 (Accessed on September 28, 2018).

30. Talaei A, Yadegari N, Rafee M, Mohamad R. Rezvanfar MR, and Moini A. Prevalence and cut-off point of vitamin D deficiency among secondary students of Arak, Iran in 2010. Indian J Endocrinol Metab 2012; 16(5): 786-90. doi: 10.4103/2230-8210.100676 (Accessed on September 28, 2018).

31. Al-Sadat N, Majid HA, Sim PY, Su TT, Dahlui M, Abu Bakar MF, Dzaki N, Norbaya S, Murray L, Cantwell MM, Jalaludin MY, MyHeART study group. Vitamin D deficiency in Malaysian adolescents aged 13 years: findings from the Malaysian Health and Adolescents Longitudinal Research Team study (MyHeARTs). BMJ Open 2016; 6: e010689. doi:10.1136/bmjopen-2015-010689 (Accessed on September 28, 2018).

32. Ashraf T, Soliman AT, De Sanctis V, Elalaily R, Bedair S and Kassem I. Vitamin D deficiency in adolescents. Indian J Endocrinol Metab 2014; 18(Suppl 1): S9-S16.

33. Harkness LS, Cromer BA. Vitamin D deficiency in adolescent females. Journal of Adolescent Health 2005; 37(1): 75 .

34. Misra M, Pacaud D, Petryk A, et al. Vitamin D deficiency in children and its management: review of current knowledge and recommendations. Pediatrics 2008; 122: 398.

35. Little Flower Augustine K, Madhavan N, Bharati K. Optimal Duration of Sun Exposure for Adequate Cutaneous Synthesis of Vitamin D in Indian Cities: An Estimate Using Satellite-Based Ultraviolet Index Data. Biomed J Sci \& Tech Res 2018; 6(2). doi:10.26717/BJSTR.2018.06.001313.

36. World Health Organistaion. Sunshine and health; How to enjoy the Sun safely 2006. https://www.who.int/uv/ publications/solaruvflyer2006.pdf?ua $=1$ (Accessed on 15th July 2019). 